\title{
Dynamic Modelling of Land Use Change Impacts on Nitrate Loads in Rivers
}

\author{
Björn Guse $^{1} \cdot$ Matthias Pfannerstill $^{1} \cdot$ Nicola Fohrer $^{1}$
}

Received: 19 May 2015 / Accepted: 28 July 2015 /Published online: 16 August 2015

(C) Springer International Publishing Switzerland 2015

\begin{abstract}
Agricultural land use practices were found to have a great impact on river water quality. Highly variable boundary conditions such as seasonal weather influence or market impacts lead to dynamic changes in the use of agricultural crops. In rural areas with a huge share of agricultural land use, these dynamics are accompanied with changes of river water quality. To quantify these impacts for the future, it is common practice to apply scenario simulations with eco-hydrological catchment models. For this, it is essential to represent spatially and temporal variations in agricultural crops. In this study, we present a dynamic modelling approach of spatial agricultural crops distribution and its impacts on nitrate loads in rivers at the catchment scale. Area proportions of crops are reproduced in a data-based approach according to the current land use situation in the catchment. Using this spatial crop distribution, the eco-hydrological model SWAT is calibrated for discharge and nitrate time series. Within scenario simulations, the spatial crop distribution is updated dynamically for each year, while non-agricultural land use areas remain constant. The dynamic approach is compared with a static land use scenario, in which the land use information is changed only once immediately at the beginning of the scenario period. Good model results were realised for discharge and nitrate loads in the calibration and validation period. The evaluation of the land use change scenarios for the period from 2021 to 2030 revealed changes in nitrate loads. The analysis of the dynamic land use update illustrates an increase in the changes between the scenarios within the modelling period. Consequently, the presented approach allows the quantification of nutrient dynamics that are related to dynamic changes of land use during the simulation period. We conclude that this study shows how the dynamic modelling leads to a more realistic temporal development of land use change and its impacts on nitrate.
\end{abstract}

Keywords Dynamic land use change $\cdot$ Land use change $\cdot$ Water quality modelling $\cdot$ Catchment modelling $\cdot$ SWAT $\cdot$ Nitrate

Björn Guse

bguse@hydrology.uni-kiel.de

1 Institute of Natural Resource Conservation, Department of Hydrology and Water Resources

Management, Christian-Albrechts-University of Kiel, Kiel, Germany 


\section{Introduction}

Agriculture land use as a major driver of environmental changes in rural areas is subject of dynamic land use changes (e.g., Chiang et al. 2010). These areas are highly influenced by different land use drivers such as increasing demand for food or bioenergy crops or the achievement of good ecological conditions (e.g., Veldkamp and Lambin 2001; Fohrer et al. 2002; Verburg et al. 2010; Lautenbach et al. 2013). These drivers of land use change affect amongst others water and nutrient cycles. Nutrient pollution from agricultural areas impacts aquatic environment and river water quality (e.g., Behrendt et al. 1999; Arheimer and Liden 2000; Rekolainen et al. 2003; Guse et al. 2007, 2015). To assess these impacts of land use change on water balance and water quality, land use scenarios are assessed with the help of eco-hydrological models (e.g., Hesse et al. 2008; Huang et al. 2009; Laurent and Ruelland 2011; Panagopoulos et al. 2011).

Land use change assessment can be further subdivided into a spatial distribution of crops as shares of arable areas and a temporal component as emphasised by Kloecking et al. (2003) and Lautenbach et al. (2013). For reliable future predictions, the spatial distribution of land use change has to be taken into account which results in typical land use patterns (e.g., Veldkamp and Lambin 2001; Fohrer et al. 2002; Niehoff et al. 2002; Kloecking and Haberlandt 2002; Verburg et al. 2010). Temporally, arable areas are highly dynamic, since farmers are able to change crop cultivations from year to year. Changes in the political-economic conditions result in a high potential of rapid changes leading to a dynamic process of shifts in the spatial crop distribution (Verburg and Veldkamp 2001; Niehoff et al. 2002; Kloecking et al. 2003; Audsley et al. 2006; Ronfort et al. 2011). This result in high changes in the nutrient pollution at the annual scale. The magnitude of the impact of these spatio-temporal modifications in agricultural crops on nutrient pollution depends among others on differences between the crops and their seasonal management such as fertilizer and tillage timing as well as soil coverage.

Dynamic spatially distributed models can be used to analyse location and timing of a longterm land use change in the future (Lambin et al. 2000). To capture these changes in land use drivers and the possibility of rapid changes in crop cultivations, a dynamic model approach is required, which includes changes in agricultural areas within the scenario period. Dynamic modelling is adapted to provide realistic estimates by considering variations in the land use conditions (Chiang et al. 2010; Pai and Saraswat 2011).

For scenario simulations of the future impact of land use change on water quality, the recent conditions of water balance and water quality need to be reproduced with an eco-hydrological model (e.g., Huang et al. 2009; Bieger et al. 2015) such as the SWAT model (Arnold et al. 1998). The SWAT model includes a detailed land management tool to carry out a spatially distributed analysis of land use change. While the SWAT model was already used for several land use change assessments (e.g., Fohrer et al. 2001, 2005; Ullrich and Volk 2009; Ghaffari et al. 2010; Strauch et al. 2013; Batelis and Nalbantis 2014; Bieger et al. 2015; Salmoral et al. 2015), only a very limited number of applications was focused on dynamic modelling of land use change (Chiang et al. 2010; Pai and Saraswat 2011). The advantage of dynamic land use modifications to represent a realistic development within the modelling period was already emphasised by Pai and Saraswat (2011) for classical land use conversion in SWAT model applications. However, a dynamic modelling of changes within agricultural areas was up to now not in the focus of land use scenario simulations.

This study investigates the dynamic change of the spatial distribution of agricultural crops in a modelling study. Measured discharge and nitrate loads for the recent conditions are 
reproduced with the SWAT model for the Treene catchment in Northern Germany. A static and a dynamic scenario approach are compared. In the static approach, the land use information immediately changed at the beginning of the simulation period. In contrast, in the dynamic approach, the land use information is updated in each year and reaches the final land use situation in the last year of the modelling period. The impact of dynamic changes of agricultural crops within the land use scenario on modelled discharge and nitrate loads are compared for the static and dynamic land use scenarios.

\section{Study Area and Data}

\subsection{Treene Catchment}

The Treene catchment belongs to the Northern German lowlands and has a catchment size of $481 \mathrm{~km}^{2}$ (hydrological station Treia) (Fig. 1). Groundwater flow is the dominant hydrological process in the northern German lowlands with low hydraulic gradients (Kiesel et al. 2010). Due to that, about one third of the agriculture areas are drained (Fohrer et al. 2007). Agriculture is the dominant land use in the Treene catchment. While grassland increases from east to west, arable land has the highest percentage in the eastern parts. The area contributions of forest and urban areas are small in the Treene catchment (Fig. 1). The Treene catchment can be sub-divided into three landscape types. The Eastern Hillands have slight slopes and more fertile soils, allowing a cultivation of high value crops, which are typical for the Northeast (Marquardt 2008). The flatter Geest landscape in the Southwest are characterised by poorer sandy soils and low fertility and can be divided into the higher and lower Geest (LANU S-H 2006). The area contributions of agricultural, forest and urban areas were stable during the last decade, while a high dynamic in the crop cultivation was observed (Marquardt 2008).

\subsection{Data}

Three input maps were implemented in the SWAT model setup: A digital elevation model (25 m resolution, (LVERMA S-H 1995)), a land use map (LVERMA S-H 2004) and a soil map (BGR 1999). The digitalized property map (Automatisierte Liegendschaftskarte, ALK) from 2004 was used in this study providing an accurate representation of the absolute percentages and spatial distribution of all land use types within the Treene catchment.

Daily discharge time series from six hydrological stations were used which capture the three landscapes within the catchment (Fig. 1). Daily mixed samples of nitrate were taken at the hydrological station Treia from 10/2010 to 09/2012 providing continuous daily time series for nitrate to calibrate and validate the SWAT model.

Information of inputs from point sources were provided by the administrative district of Schleswig-Flensburg for several sewage plants within the Treene catchment to estimate monthly average inputs of nitrate from point sources. Daily time series of different climate variables of four climate stations (Fig. 1) were provided by the German Weather Service (1950-2012). Precipitation data were corrected with a monthly factor derived by Richter (1995) for Germany.

Climate data from the STAtistical Regional model (STAR) (Orlowsky et al. 2008) were used as input for the SWAT model to carry out land use scenarios for the future period (20132030). The STAR data were provided from the Potsdam Institute for Climate Impact Research 


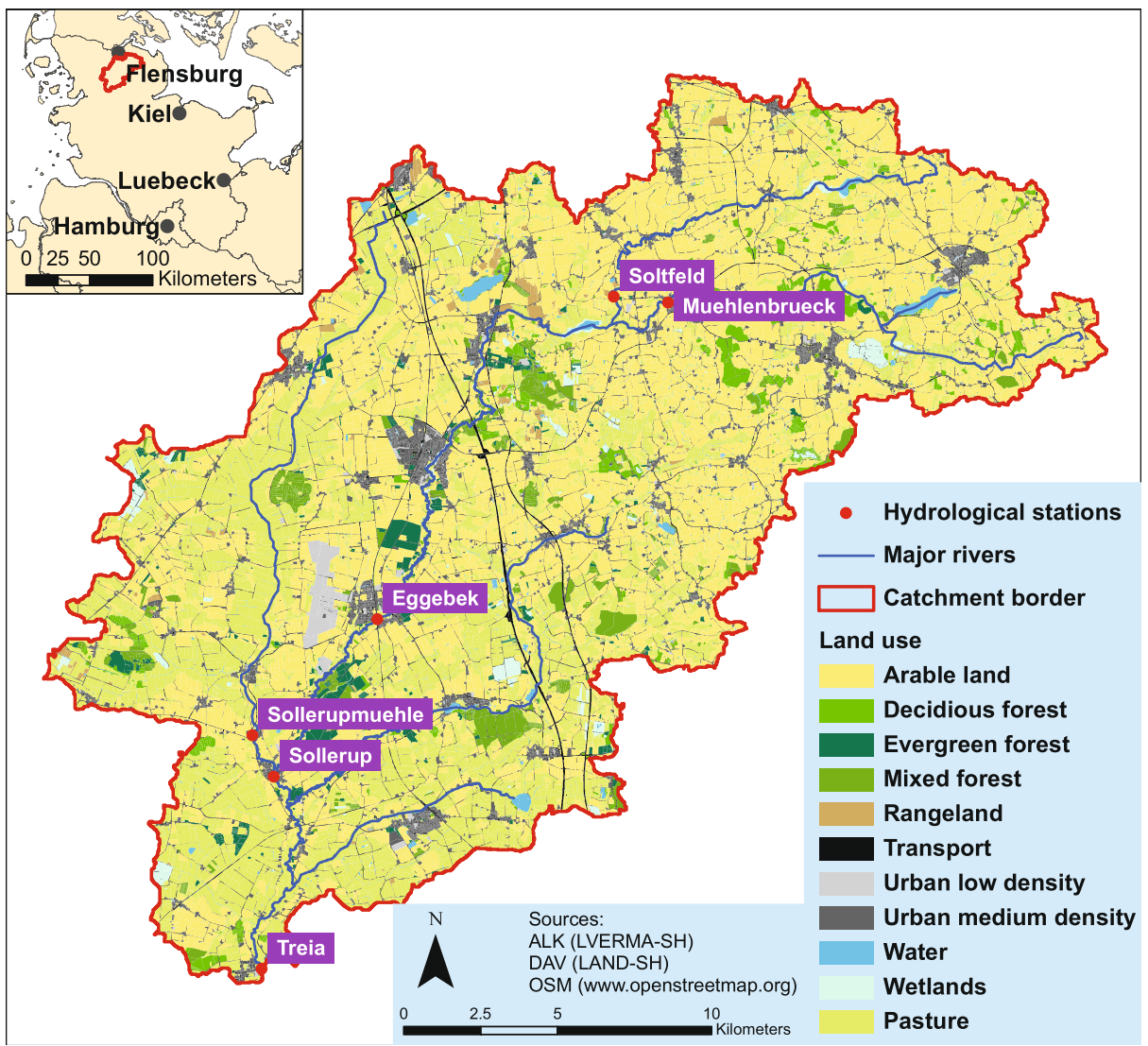

Fig. 1 Land use (ALK, (LVERMA S-H 2004)) in the Treene catchment and available discharge stations (modified after Guse et al. $(2014,2015)$ ). The geographic location of the catchment is shown in the small map

(PIK) as described in Oesterle (2001) and Conradt et al. (2012). Constant climate conditions were assumed by using a future climate data set with no increase in temperature and an average mean precipitation according to Hesse et al. (2008).

Crop data from community level were used comparable to studies with the SWAT model from Liersch (2005) and Lautenbach et al. (2013). The federal administration for statistics of Hamburg and Schleswig-Holstein (Statistik Nord) provides detailed information of agriculture crop shares at the community level was available for the years 2003, 2007 and 2010 (agrarian structure statistics).

Recent land use changes were observed in the study catchment. Figure 2 shows the spatial distribution of agricultural crops in the Treene catchment for the years 2003 and 2010. Typical spatial patterns of agricultural crops are related to the main landscape units (Geertz 2012). The Eastern Hillands are characterised by high shares of high value crops such as wheat, barley or rape. In contrast, the Geest landscapes in the western parts are dominated by corn fields. Recent developments in the crop cultivations can be detected by comparing both maps. They illustrate the high extent of changes in the crop cultivations within seven years. The most relevant change is related to the corn share. The percentage of corn areas is significantly higher in 2010 (Fig. 2b) in comparison to 2003 (Fig. 2a) in all landscapes types due to the rising 


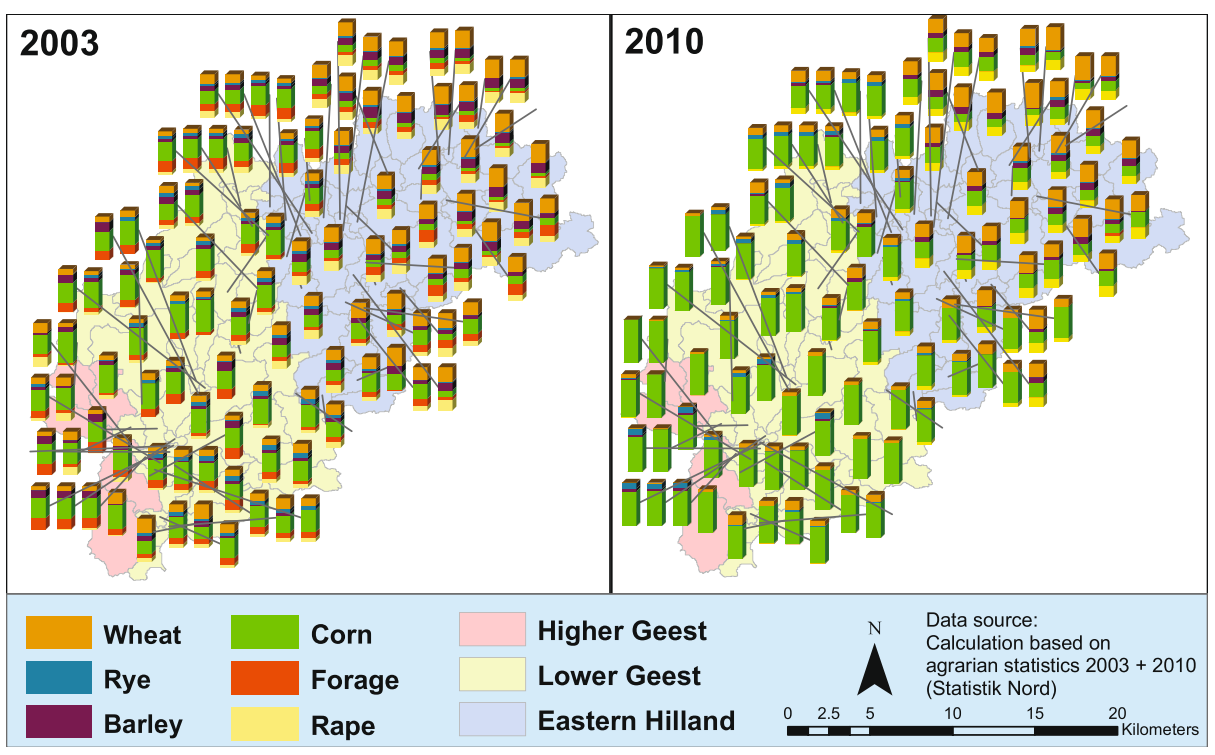

Fig. 2 Spatial land use distribution in 2003 and 2010 in the Treene catchment shown as average values for each subbasin

demand for energy crops that are used for biogas production (Marquardt 2008). While corn was already the dominating crop in the Geest in 2003, the corn share also increased to one third of the crop share in the Eastern Hilland. During this period from 2003 to 2010 all other crop shares were reduced. Thus, the comparison of recent developments in the crop distributions in 2003 and 2010 illustrates a dynamic change in shares of agricultural crops.

\section{Models and Methods}

\subsection{Soil and Water Assessment Tool (SWAT)}

To reproduce the hydrological conditions in the Treene catchment, the Soil and Water Assessment Tool (SWAT) (Arnold et al. 1998; Arnold and Fohrer 2005) was used to calculate water balance and nutrient processes. The eco-hydrological SWAT model is semi-distributed with subbasins as the finest spatially located unit. Hydrological response units (HRUs) are lumped within the subbasins with different combinations of land use, soil and slope class. The water balance equation is resolved at the land phase for each subbasin including different processes ranging from precipitation (rain or snow), evapotranspiration to runoff (surface, subsurface and groundwater flow) and soil water storage. In the water phases, all subbasins are connected and routed along the river network. The SWAT model provides several outputs for each subbasin.

In the land management tool of the SWAT model, different crop rotations are implemented at HRU level. For each crop rotation, information about specific crops, harvest time, fertilizer and tillage operations are required. Crop types can be changed in every year of a crop rotation. Fertilizers and manures are the most important nutrient input within agricultural areas. The nitrogen cycle is modelled in soil and groundwater. Nitrate removal from the soil is modelled 
by plant uptake, leaching, transformations and soil erosion. Nitrate is transported via surface runoff, tile flow, lateral flow and groundwater flow (Neitsch et al. 2011; Haas et al. 2015).

SWAT 2009 with revision number 488 was used in this study. Additional information of the SWAT model are available in the theoretical documentation (Neitsch et al. 2011).

\subsubsection{SWAT Model Set-Up}

The SWAT model was set up for the Treene catchment as described in Guse et al. (2014). In each subbasin, three slope classes were separated $(<1.25,1.25-3,>3 \%)$. Land use and soil types which contribute less than 5 or $10 \%$, respectively, to a subbasin area were reclassified. Soil and crop databases were used from a former SWAT study (Fohrer et al. 2013). Tile flow was implemented using intially the parameter values from Kiesel et al. (2010) for HRUs with agriculture, pasture or rangeland as land use, a soil type with a high water table which belong to the lowest slope class $(<1.25)$.

Agriculture areas were subdivided into five sub-areas representing five crop rotations (see Table 1). These crop rotations include the major crops in the Treene catchment and were used in Guse et al. (2015).

To split the agricultural areas, the land use splitting tool was used within the SWAT preprocessing. Owing to this subdivision, the number of HRUs with agricultural land use increased from 570 to 2850 . Subsequently, the preprocessing resulted in 108 subbasins (Fig. 1) and 4524 HRUs.

This splitting of the agricultural areas allows for a detailed consideration of the spatial distribution of the crops in each subbasin. Contributions of the five crop rotations to the agriculture areas were adjusted for each subbasin according to the real spatial distribution of the crops.

The information of agriculture crops is available at community level, while the subbasin level is used in SWAT. Thus, the information from the community level was transformed to the subbasin level under consideration of an accurate spatial distribution of crops. The methodical approach for the spatial distribution of crops in the subbasins is described as follows:

The statistical agrarian information provided the percentage of crops in each community (crop quota). The total area which is covered by a certain crop was detected by overlaying the community map with the agricultural areas provided from the land use map. In a next step, the subbasins were combined with the community map to estimate the contribution of the communities to the different subbasins. This analysis provided the percentages to which a community belonged to a subbasin. By combining this community share of a subbasin with the crop quota, the percentage of each crop to a subbasin was determined.

The crop shares were used as input for the SWAT model. Since the SWAT model required crop rotations, the crop shares were converted into shares of the five crop rotations. This conversion from crops to crop rotations was carried out for the years 2003, 2007 and 2010.

Table 1 Crop rotations

\begin{tabular}{ll}
\hline WHE & Winterwheat \\
CSI & Corn silage \\
RWB & Winterrape - Winterwheat - Winterbarley \\
CSR & Corn silage - Corn silage - Rye \\
CPP & Corn silage - Pasture - Pasture \\
\hline
\end{tabular}


Then, the shares of the five crop rotations were estimated for each subbasin and implemented into the SWAT model.

\subsubsection{Dynamic Land Use Modelling}

The dynamic change of the land use areas within the modelling period was realised by using the land use update tool in SWAT (Arnold et al. 2010; Pai and Saraswat 2011). The area of HRUs as the finest spatial unit is modified each time when new land use information is provided. This means that the fractions of the HRUs with agricultural land use within the subbasin are changed, while maintaining the total area of the subbasin constant. Changes were thus only implemented between the agricultural HRUs, i.e., the five crop rotations. The model simulation was started with the land use situation in 2003. Then, the crop shares within the subbasins were updated in 2007 and 2010 dynamically so that the observed crop distribution in these years was considered.

\subsection{Model Calibration and Evaluation}

An adequate modelling of water balance and water quality for present conditions is a prerequisite for future simulations of land use change. To achieve reliable simulation results, hydrological models have to be adapted to the conditions of the study catchment by setting the model parameters to realistic values. There is a trade-off in the selection of a common parameter set between these different processes in this multi-variable calibration of discharge and nitrate (Van Griensven et al. 2006; Ahmadi et al. 2014). The model performance of both discharge and nitrate needs to be analysed to achieve a realistic estimation of the water and nitrate cycle.

The model period includes the recent period from 1997 to 2012 with a warm-up period of four years for calibration (2001-2005) and validation period (2006-2012). Discharge time series from six hydrological stations were available (see Fig. 1). These hydrological stations were spatially distributed in the landscape and represent different sub-catchment sizes. The discharge was calibrated in a multi-site model evaluation procedure (e.g., Cao et al. 2006; Ahmadi et al. 2014). The most relevant parameters were varied between the six hydrological stations to capture the variations between the main landscapes (Eastern Hilland and Geest) of the study catchment.

The two years of water quality measurements were subdivided into one year for the calibration (10/2010-09/2011) and one year for the validation (10/2011-09/2012). Nitrate loads were calibrated for the catchment outlet Treia in two steps. At first, the relevant model parameters were determined manually. In this way, all model parameters were set to reasonable values leading to an acceptable model performance. As a second step, an automatic calibration with the most relevant parameters was carried out in the $\mathrm{R}$ environment ( $\mathrm{R}$ Core Team 2013) to refine the parameter values. For this, the latin hypercube method implemented in the $\mathrm{R}$ package FME (Soetaert and Petzoldt 2010) was selected as described in Pfannerstill et al. (2014b) and Pfannerstill et al. (2014a).

The comparison of the modelled with the measured discharge was realised visually and by calculating three performance measures for the continuous discharge and nitrate time series of the calibration period. Nash-Sutcliffe coefficient of efficiency (CE) (Nash and Sutcliffe 1970), the percentual bias (PBIAS) and the RMSE standard deviation error (RSR) were selected as performance measures. These three performance measures are 
focused on different aspects of the discharge time series. PBIAS and RSR were calculated so that an overestimation of the measured discharge series is denoted by a positive value. They were described more in detail in Legates and McCabe Jr. (1999), Dawson et al. (2007) and Jachner et al. (2007). Moriasi et al. (2007) suggested a threshold of NSE $>0.65, \operatorname{PBIAS}<15 \%$ and $\mathrm{RSR}<0.6$ for monthly model evaluations. These suggested thresholds were interpreted to be applicable to daily model evaluations studies as exemplarily shown by Pfannerstill et al. (2014a).

\subsection{Land Use Scenario Simulations}

A land use scenario developed by Geertz (2012) was used in a static and a dynamic approach. In this land use scenario, only the shares of agricultural crops were changed, while maintaining all other areas constant. The corn share was lower in 2030 compared to 2010 while the shares of pastures were highly increasing until 2030, especially in the Geest landscapes. Also the rape share was increasing at the expense of wheat mainly in the Eastern Hillands with more fertile soils.

The crop shares of the baseline and the future land use scenario were then converted into the five crop rotations (Table 1). Figure 3 shows the spatial distribution of the five crop rotations within the future land use scenario compared to the baseline scenario. The shares of crop rotations Corn-Pasture-Pasture and Rape-Wheat-Barley increased while the corn and wheat monocultures were reduced.
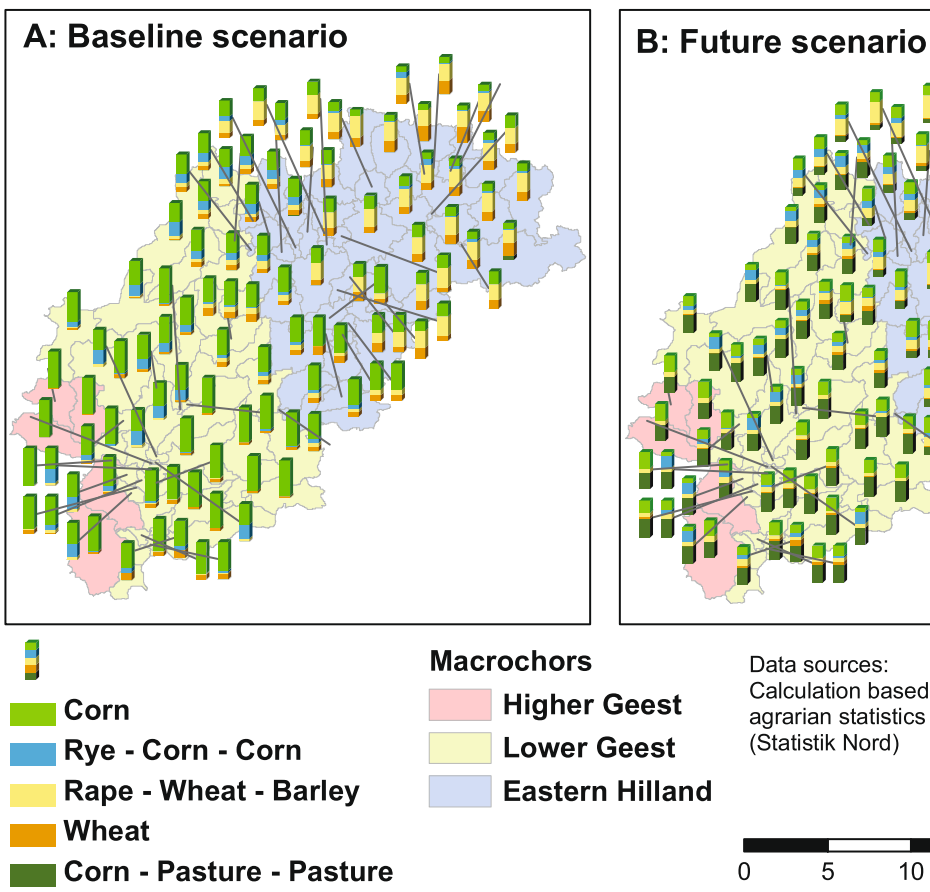

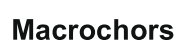

Higher Geest

Lower Geest

Eastern Hilland

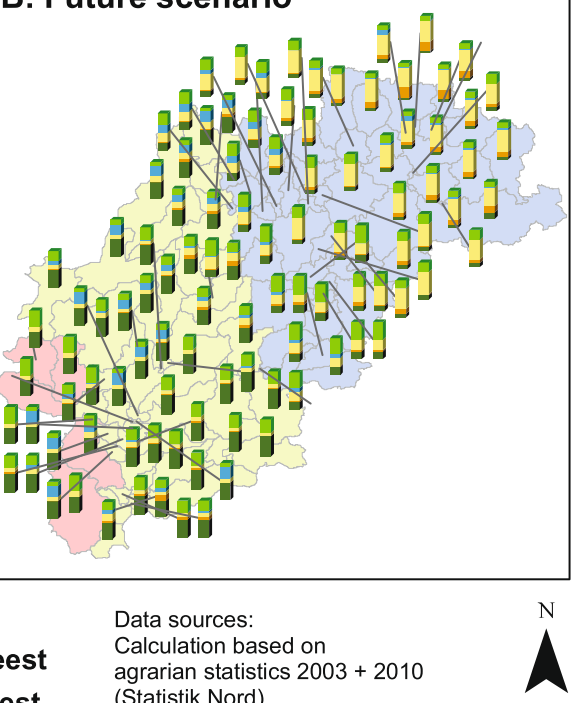
(Statistik Nord)

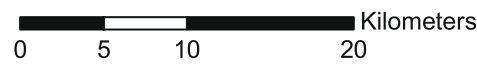

Fig. 3 Comparison of the five rotations between the baseline and the future scenario for each subbasin of 2030 for the Treene catchment 


\subsubsection{Static Approach}

In the static land use scenario, the shares of the crop rotations as estimated for 2030 were directly implemented from 2013. Thus, the shares of the crop rotations were constant during the whole future simulation period from 2013 to 2030 (Fig. 4). Thus, it was assumed that the final land use situation as predicted in the land use scenario already occurred in 2013.

\subsubsection{Dynamic Approach}

In the dynamic land use scenario, the shares of the crop rotations were updated continuously in each year from 2013 to 2030 by using the land use update tool of the SWAT model. Thus, the model results showed dynamically the effect of the modifications in the shares of the crop rotations within the period from 2013 to 2030 .

The dynamic update of the crop rotations was shown in Table 2 exemplarily for the crop rotation Rape-Wheat-Barley (RWB) for subbasin 15. The shares of the crop rotation for 2003, 2007 and 2010 were estimated according to the agrarian structure data. The future scenario provided crop shares for 2015, 2020 and 2030. Between these intermediate points, the change per year varied as demonstrated in the last column of Table 2.

Figure 4 showed the dynamic update from 2013 to 2030 as average shares for crop rotation for the whole study catchment in the dynamic land use scenario. The crop shares were changed in each year. A continuous increase of the shares of rape and pasture at the expense of wheat and corn silage was modelled from 2015 to 2020 and from 2020 to 2030.

\subsubsection{Scenario Evaluation}

In addition to the static and dynamic land use change scenarios, a baseline scenario with the spatial distributed crop shares of 2010 was simulated with no changes until 2030. The simulations of all scenarios were analysed for an evaluation period from 2021 to 2030. Modelled discharge and nitrate load time series of the static and dynamic land use change
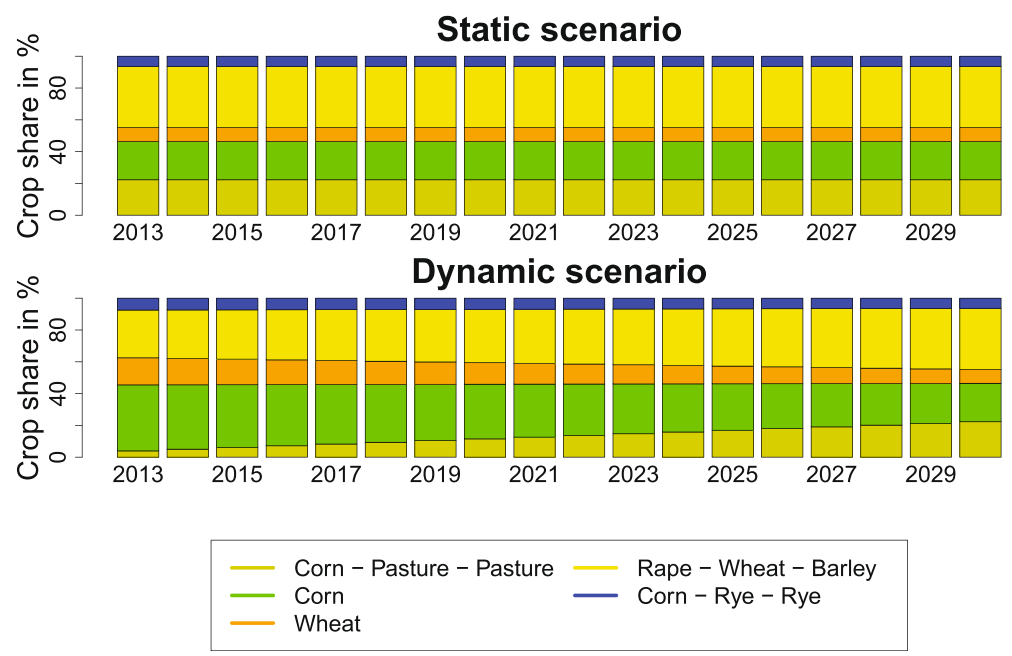

Fig. 4 Dynamic change in crop shares within the Treene catchment for the future land use scenarios 
Table 2 Dynamic change in the contribution of a crop rotation

Wheat-Barley for subbasin 15

\begin{tabular}{llll}
\hline Year & Origin & $\begin{array}{l}\text { Share of } \\
\text { crop rotation } \\
\%\end{array}$ & $\begin{array}{l}\text { Change } \\
\text { per year } \\
\%\end{array}$ \\
\hline 2003 & Data & 34.96 & \\
2007 & Data & 37.18 & +0.55 \\
2010 & Data & 43.54 & +2.12 \\
2015 & Scenario runs & 46.90 & +0.68 \\
2020 & Scenario runs & 51.10 & +0.84 \\
2030 & Scenario runs & 55.09 & +0.40 \\
\hline
\end{tabular}

scenarios were compared with the baseline scenario. The effect of the dynamic update of crop shares on discharge and nitrate was furthermore investigated by comparing differences in annual average values between both land use scenarios and the baseline scenario.

\section{Results}

\subsection{Water Balance and Water Quality Modelling}

The SWAT parameter values of model calibration are shown in Table 3. The initial parameter values for curve number CN2 and maximum canopy storage (CANMX) were adapted to the different land use types. Whereas the majority of the parameters were constant in the catchment, the most influential groundwater parameters GW_DELAY, ALPHA_BF, RCHRG_DP and an evaporation parameter ESCO (Guse et al. 2014) spatially varied within the catchment.

Measured and modelled discharge time series were compared for the catchment outlet Treia in Fig. 5 for the whole modelling period from 2000 to 2012. This figure illustrates a satisfying fit of the modelled and measured discharge time series. The discharge dynamic was generally well reproduced by the SWAT model. The three performance measures illustrate the good performance of SWAT for discharge for the six hydrological stations (Table 4) both for calibration and validation period. The PBIAS is between -8 and $+25 \%$ for calibration and between -3 and $+20 \%$ for validation showing a good performance for five stations in the calibration and four in the validation. The $\mathrm{CE}$ ranges between 0.65 and 0.82 for calibration and between 0.58 and 0.80 for validation. For both CE and RSR, the performance is good or very good for all stations except of the validation for station Sollerupmuehle.

Figure 6 shows the comparison of measured and modelled time series for nitrate loads at the gauging station Treia. Both measured and modelled time series show the typical seasonal patterns of high values in winter and lower values in summer. The peaks of nitrate were well reproduced leading to a high $\mathrm{CE}$, which was even higher in the validation period. Shortcomings for nitrate were an overestimation in the recession phase and an underestimation in phases of low nitrate loads. The calibrated values of SWAT model parameters for nitrate are illustrated in Table 3. As shown in the low values of the PBIAS, the magnitude of nitrate loads was satisfyingly reproduced which is illustrated in almost no bias in the calibration and only a slight underestimation in the validation period. The model performance for nitrate is good for all three performance measures both in calibration and validation. 
Table 3 List of SWAT model parameters

\begin{tabular}{|c|c|c|c|c|}
\hline Parameter & Short name & Type & Final & Unit \\
\hline Melt factor for snow on December 21 & SMFMN & Absolute & 2.5 & $\mathrm{~mm} \mathrm{H} 2 \mathrm{O} /{ }^{\circ} \mathrm{C}$ \\
\hline Maximum canopy storage & CANMX & Absolute & $0-9.55$ & \\
\hline Curve number & $\mathrm{CN} 2$ & Absolute & $27-67$ & \\
\hline Surface runoff lag coefficient & SURLAG & Absolute & 2.9 & days \\
\hline Available water capacity of a soil layer & SOL_AWC & Add & 0.10 & \\
\hline Saturated hydraulic conductivity & SOL_K & Multiply & 5.86 & $\mathrm{~mm} / \mathrm{h}$ \\
\hline Plant uptake compensation factor & EPCO & Absolute & 0.86 & \\
\hline Threshold depth of water for revaporation & REVAPMN & Absolute & 20 & $\mathrm{~mm}$ \\
\hline Groundwater delay time & GW_DELAY & Absolute & $3-10$ & days \\
\hline Baseflow alpha factor & ALPHA_BF & Absolute & $0.01-0.03$ & days \\
\hline Deep aquifer percolation fraction & RCHRG_DP & Absolute & $0.02-0.35$ & \\
\hline Soil evaporation compensation factor & ESCO & Absolute & $0.5-0.9$ & \\
\hline NO3 percolation & NPERCO & Absolute & 0.823 & \\
\hline NO3 uptake distribution & N_UPDIS & Absolute & 9 & \\
\hline Mineralization of active organic nutrients & $\mathrm{CMN}$ & Absolute & 0.00015 & \\
\hline $\mathrm{N}$ concentration in rainfall & $\mathrm{RCN}$ & Absolute & 3.9 & $\mathrm{mg} / 1$ \\
\hline Residue decomposition coefficient & RSDCO & Absolute & 0.05 & \\
\hline Denitrification threshold & SDNCO & Absolute & 1.1 & \\
\hline Denitrification exponential rate coefficient & $\mathrm{CDN}$ & Absolute & 3 & \\
\hline NO3 half-life in shallow aquifer & HLIFE_NGW & Absolute & 117.6 & days \\
\hline
\end{tabular}

The column 'Type' indicates whether the range is an absolute range or an additive or multiplicative factor

\subsection{Land Use Scenario Simulations}

The results of the land use scenario simulations for discharge and nitrate in the baseline and the future land use scenarios are shown in Fig. 7 by comparing the static and dynamic modelling approach. Discharge has the highest values in winter and the lowest in summer and autumn. This seasonal pattern coincides with the recent period (see Fig. 5). It can also be observed that years with relatively high discharge values as well as with lower values are included in the ten years of land use scenario simulations. There are almost no changes in discharge between the scenarios.

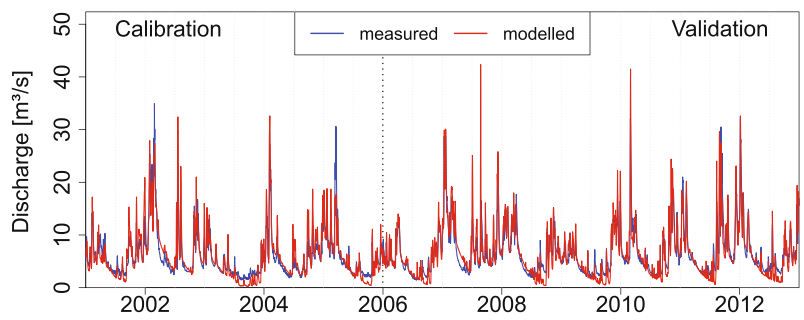

Fig. 5 Comparison of measured (in blue) and modelled discharge time series (in red) for the hydrological station Treia for the calibration and validation periods 
Table 4 Performance measures for calibration and validation period for the hydrological station Treia

\begin{tabular}{|c|c|c|c|c|c|c|c|}
\hline \multirow[t]{2}{*}{ Hydrological station } & \multirow[t]{2}{*}{ Variable } & \multicolumn{3}{|c|}{ Calibration } & \multicolumn{3}{|c|}{ Validation } \\
\hline & & $\mathrm{CE}$ & PBIAS & RSR & $\mathrm{CE}$ & PBIAS & RSR \\
\hline Soltfeld & Discharge & 0.73 & 25.2 & 0.52 & 0.66 & 20.4 & 0.58 \\
\hline Muehlenbrueck & Discharge & 0.82 & 12.6 & 0.43 & 0.80 & 5.2 & 0.44 \\
\hline Eggebek & Discharge & 0.72 & 4.3 & 0.53 & 0.72 & -3.3 & 0.53 \\
\hline Sollerupmuehle & Discharge & 0.65 & 8.5 & 0.59 & 0.58 & 17.4 & 0.65 \\
\hline Sollerup & Discharge & 0.72 & -8.2 & 0.53 & 0.71 & 1.4 & 0.46 \\
\hline Treia & Discharge & 0.79 & 3.2 & 0.46 & 0.80 & -0.2 & 0.44 \\
\hline Treia & Nitrate & 0.62 & 1 & 0.61 & 0.74 & -8.3 & 0.51 \\
\hline
\end{tabular}

For discharge the calibration period was from 2001 to 2005 and the validation from 2006 to 2010 . The nitrate parameters were calibrated from $10 / 2010$ to $09 / 2011$ and validated from 10/2011 to 09/2012. CE Nash-Sutcliffe, PBIAS Percent Bias, RSR RMSE standard deviation error

The typical seasonal nitrate dynamic with low nitrate loads in summer is also observed in the land use scenarios. In contrast to discharge, Fig. 7 shows that the nitrate loads vary among the future and the baseline scenario. Differences in nitrate loads between the scenarios are related to all magnitudes. Since the differences in discharge are low between the scenarios, a comparison of the scenarios for nitrate concentrations would lead to similar patterns.

To analyse the differences between the static and dynamic land use scenarios, differences in the annual average nitrate loads compared to the baseline scenario were calculated (Fig. 8). In both land use scenarios, nitrate loads were reduced compared to the baseline scenario. The static land use scenario was characterised by a strong reduction at the beginning and the end of the simulation period, while the impacts were lower in middle phase. In the dynamic approach, the differences generally increased within the model evaluation period. The differences increased from 2021 to 2023, following by five years with relatively low differences. Finally, the highest differences in nitrate loads occurred in the last two years (2029-2030).

The modelling of nitrate loads was not only affected by changes in the crop shares but also by variations in climatic and hydrologic situation within the evaluation period. Intermediate years within lower differences occurred in dry years with low discharges in the middle of the scenario period (see Fig. 7).

When comparing the static and the dynamic land use scenario, it becomes apparent that the differences between them were decreasing towards the end of the simulation period.

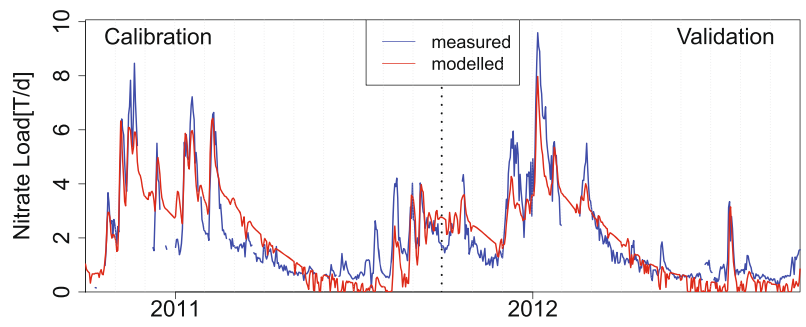

Fig. 6 Comparison of measured (in blue) and modelled nitrate time series (in red) for the hydrological station Treia 

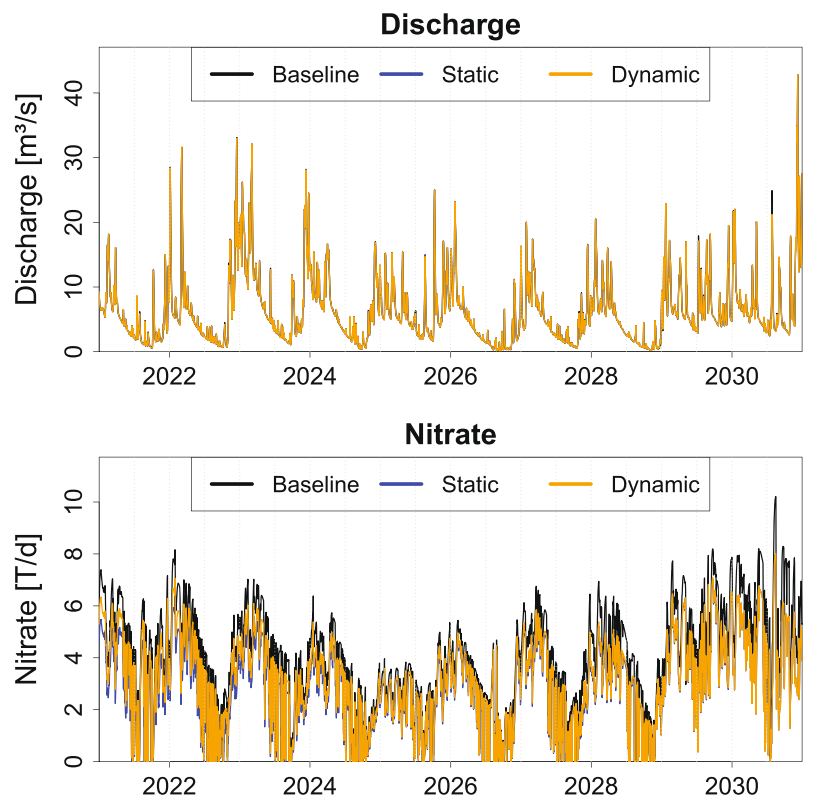

Fig. 7 Land use scenarios for discharge and nitrate for the station Treia

\section{Discussion}

In this study, dynamic changes of agricultural crop rotations and their spatial distribution were analysed and their effect on the modelled nitrate load was assessed. Dynamic and static land use scenarios were compared with a baseline scenario. As follows, the potential of dynamic change modelling and the effects of land use change on the modelled discharge and nitrate were discussed.

As a prerequisite for the land use simulations, an eco-hydrological model was calibrated in a multi-site and multi-objective approach. The evaluation of three performance metrics for discharge and nitrate leads to a balanced result that fulfils the performance criteria both for discharge and nitrate.

Within the land use simulations, the percentages of crop shares changed gradually from year to year in the dynamic land use scenario as shown in Fig. 4. Compared to this approach,

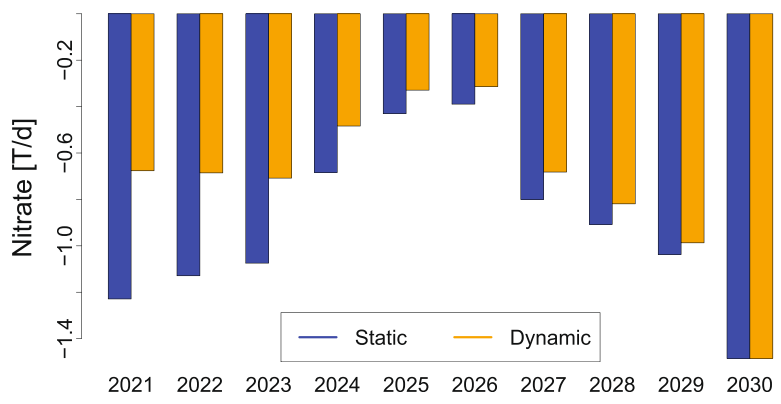

Fig. 8 Differences in annual average nitrate loads between the two future land use scenarios (static and dynamic) and the baseline scenario for each year of the evaluation period at the catchment outlet Treia 
the classical static land use scenario used the final crop shares of 2030 for the whole future simulation period. The largest difference in the crop shares were observed at the beginning of the simulation period.

The differences among the crop shares between the static and dynamic scenario were very large in 2013 and identical in 2030. While the static approach assumes that the crop shares changed immediately from 2012 to 2013, the dynamic update of the crop shares in the dynamic approach did not only show the final conditions at the end of simulation period, but also intermediate steps based on a gradual increase in the change of agricultural crops. In this way, the temporal development until the end of the period was considered. Thus, dynamic changes in crop shares led to a more precise representation of crop shares and their effects on nitrate loads.

The decrease in the differences between the static and dynamic scenarios for the crop shares resulted also in same situation for the modelled nitrate loads. In the static approach, the changes in nitrate loads were overestimated compared to the dynamic approach.

The temporal development in nitrate loads was affected by crop distributions as well as by the interannual variations in the climate conditions. While the crop distribution influenced the differences between the static and dynamic land use scenario, the hydroclimatic situation affected in particular variations between the future and the baseline scenario.

The dynamic approach provides realistic future developments for all years and not only for the end of the scenario period. As also stated by Pai and Saraswat (2011), the temporal component of land use change is better assessed in the dynamic approach. Thus, nitrate loads are assumed to be more realistically estimated.

As in all scenario runs, the simulation results have to be interpreted based on the assumptions which were included in the scenario storyline (Verburg et al. 2006). This study was focused on the comparison of static and dynamic land use scenarios to demonstrate the differences between both scenario methods. We are aware that a scenario focusing on other drivers of land use change would lead to a different response.

The continuous slight change in nitrate loads in the dynamic and one rapid change in the static scenarios were detected as a characteristic of these two approaches. In its quality, this statement can be generalised and will only vary in absolute values and in the direction of changes between different scenarios.

In terms of agricultural related scenarios, economic decisions of the farmers and landowners are the main driver for land-use change. However, political guidelines may influence these decisions by modifying the requirements for farmers to receive subsidies (Audsley et al. 2006; Ronfort et al. 2011). According to these rapid changing boundary conditions, the contribution of certain crops to the agricultural area may change dynamically (Verburg and Veldkamp 2001). Different land use change drivers may lead to different effects on water quality (Guse et al. 2015).

In the context of land use management, the dynamic approach could also be helpful to assess the achievements of the Water Framework Directive, since land use change could affect in addition to water quality also aquatic biota (Sundermann et al. 2013; Kail et al. 2015; Guse et al. 2015). In the case of estimating impacts of land use change on the aquatic biota, the dynamic update approach leads to a more realistic simulation for the whole modeling period. The dynamic approach shows not only the final conditions at the end of simulation period, but also intermediate steps based on the gradual increase in the change of agricultural crops. Thus, the resulting impact on hydrologic and aquatic variables can be assessed continuously. 


\section{Conclusion}

In this study, the impact of land use change on discharge and nitrate load was analysed. The core focus was a dynamic update of spatially distributed crop shares in comparison to the classical static approach. For these land use scenarios, the spatial patterns of agricultural crops were satisfyingly reproduced by using data of crop shares at the community level and were implemented spatially distributed into the SWAT model. The SWAT model reproduces satisfyingly measured discharge and nitrate time series for recent conditions.

The main outcomes are:

1. The comparison of the future land use scenarios simulations with the baseline conditions results in small changes in discharge. In contrast, changes in the crop shares within the agricultural areas lead to changes in nitrate loads in a relevant extent.

2. The differences between the land use change and the baseline scenario are increasing in the dynamic approach due to the successively increasing differences in the crop shares. In contrast, the differences are constant in the static approach due to the immediate change of the crop shares. Within the scenario period, the differences between the static and dynamic scenario decreases.

These model results show that a dynamic land use change approach is able to reproduce the temporal development of changes in land use and their impacts on the catchment conditions. Thus, the dynamic approach provides more realistic future nitrate load estimations due to the continuous modifications of the crop shares.

Acknowledgments We thank Schleswig-Holstein Agency for Coastal Defence, National Park and Marine Conservation of Schleswig-Holstein (LKN-SH) for the discharge data, the Landesamt fuer Natur und Umwelt Schleswig-Holstein (LANU) for the river map (Digitales Anlagenverzeichnis, DAV), the German Weather Service (DWD) for the climate data and the Potsdam Institute for Climate Impact Research (PIK) for the STAR data. Furthermore, we thank the federal statistic office of Schleswig-Holstein and Hamburg (Statistik Nord) for the agrarian structure data (Agrarstrukturerhebung) of the years 2003, 2007 and 2010.

This study is part of the IWRM-net project IMPACT and has been funded by the German Federal Ministry for Education and Research (BMBF) (grant number 02WM1136). This project has been carried out with financial support of a scholarship for the second author by the German Environmental Foundation (DBU).

We thank Jörn Geertz for developing the land use scenario as well as Thea-Lina Mueller and the laboratory crew of the Institute of Natural Resources Conservation of the Christian-Albrechts-University of Kiel for carrying out the water quality analysis. We would like to thank the community of the open source software R, which was used for the majority of the analysis.

\section{References}

Ahmadi M, Ascough JC II, DeJonge K, Arabi M (2014) Multisite-multivariable sensitivity analysis of distributed watershed models: enhancing the perceptions from computationally frugal methods. Ecol Model 279:54-67

Arheimer B, Liden R (2000) Nitrogen and phosphorus concentrations from agricultural catchments - influence of spatial and temporal variables. J Hydrol 227:140-159

Arnold J, Fohrer N (2005) SWAT2000: current capabilities and research opportunities in applied watershed modelling. Hydrol Process 19:563-572

Arnold J, Srinivasan R, Muttiah R, Williams J (1998) Large area hydrologic modeling and assessment part I: model development. J Am Water Resour Assoc 34:73-89 
Arnold JG, Gassman PW, White MJ (2010) New developments in the SWAT ecohydrology model. Proceedings of the 21st Century Watershed Technology: Improving Water Quality and Environment, Universidad EARTH Costa Rica

Audsley E, Pearn KR, Simota C, Cojocaru G, Koutsidou E, Rounsevell MD, Trnka M, Alexandrov V (2006) What can scenario modelling tell us about future European scale agricultural land use, and what not? Environ Sci Pol 9:148-162

Batelis SC, Nalbantis I (2014) Potential effects of forest fires on streamflow in the Enipeas river basin, Thessaly, Greece. Environ Process 1:73-85

Behrendt H, Huber P, Ley M, Opitz D, Schmoll O, Scholz G, Uebe R (1999) Naehrstoffbilanzierung der Flussgebiete Deutschlands. UBA-Texte 75/99.

BGR (1999) Bodenuebersichtskarte im Massstab 1:200000, Verbreitung der Bodengesellschaften. Bundesanstalt fuer Geowissenschaften und Rohstoffe, Hannover

Bieger K, Hoermann G, Fohrer N (2015) The impact of land use change in the Xiangxi catchment (China) on water balance and sediment transport. Reg Environ Chang 15:485-498

Cao W, Bowden WB, Davie T, Fenemor A (2006) Multi-variable and multi-site calibration and validation of SWAT in a large mountainous catchment with high spatial variability. Hydrol Process 20:1057-1073

Chiang L, Chaubey I, Gitau MW, Arnold JG (2010) Differentiating impacts of land use changes from pasture management in a Ceap watershed using the SWAT model. Trans ASABE 53(5):1569-1584

Conradt T, Koch H, Hattermann FF, Wechsung F (2012) Precipitation or evapotranspiration? Bayesian analysis of potential error sources in the simulation of sub-basin discharges in the Czech Elbe River basin. Reg Environ Chang 12:649-661

Dawson CW, Abrahart RJ, See LM (2007) HydroTest: a web-based toolbox of evaluation metrics for the standardised assessment of hydrological forecast. Environ Model Software 22:1034-1052

Fohrer N, Haverkamp S, Eckhardt K, Frede HG (2001) Hydrologic response to land use changes on the catchment scale. Phys Chem Earth B 26(7-8):577-582

Fohrer N, Moeller D, Steiner N (2002) An interdisciplinary modelling approach to evaluate the effects of land use change. Phys Chem Earth 27:655-662

Fohrer N, Haverkamp S, Frede HG (2005) Assessment of the effects of land use patterns on hydrologic landscape functions: development of sustainable land use concepts for low mountain range areas. Hydrol Process 19: $659-672$

Fohrer N, Schmalz B, Tavares F, Golon J (2007) Modelling the landscape water balance of mesoscale lowland catchments considering agricultural drainage systems. Hydrol Wasserbewirtsch 51(4):164-169

Fohrer N, Dietrich A, Kolychalow O, Ulrich U (2013) Assessment of the environmental fate of the herbicides Flufenacet and Metazachlor with the SWAT model. J Environ Qual. 43(1):75-85. doi:10.2135/jeq2011.0382

Geertz J (2012) Land use scenarios for the river Treene catchment in Northern Germany. Bachelor thesis, Brandenburgische Technische Universitaet Cottbus

Ghaffari G, Keesstra S, Ghodousi J, Ahmadi H (2010) SWAT-simulated hydrological impact of land use change in the Zanjanroud basin, Northwest Iran. Hydrol Process 24(7):892-903

Guse B, Bronstert A, Rode M, Tetzlaff B, Wendland F (2007) Application of two phosphorus models with different complexities in a mesoscale river catchment. Adv Geosci 11:77-84

Guse B, Reusser DE, Fohrer N (2014) How to improve the representation of hydrological processes in SWAT for a lowland catchment - temporal analysis of parameter sensitivity and model performance. Hydrol Process 28: 2651-2670. doi:10.1002/hyp. 9777

Guse B, Kail J, Radinger J, Schroeder M, Kiesel J, Hering D, Wolter C, Fohrer N (2015) Eco-hydrologic model cascade: Simulating land use and climate change impacts on hydrology, hydraulics and habitats for fish and macroinvertebrates. Sci Total Environ 533:542-556. doi:10.1016/j.scitotenv.2015.05.078

Haas M, Guse B, Pfannerstill M, Fohrer N (2015) Detection of dominant nitrate processes in eco-hydrological modelling with temporal parameter sensitivity analysis. Ecol Model. doi:10.1016/j.ecolmodel.2015.07.009

Hesse C, Krysanova V, Pazolt J, Hattermann F (2008) Eco-hydrological modelling in a highly regulated lowland catchment to find measures for improving water quality. Ecol Model 218(1-2):135-148

Huang S, Hesse C, Krysanova V, Hattermann F (2009) From meso- to macro-scale dynamic water quality modelling for the assessment of land use change scenarios. Ecol Model 220(19):2543-2558

Jachner S, van den Boogaart KG, Petzoldt T (2007) Statistical methods for the qualitative assessment of dynamic models with time delay (R package qualv). J Stat Softw 22:1-30

Kail J, Guse B, Radinger J, Schroeder M, Kiesel J, Kleinhans M, Schuurman F, Fohrer N, Hering D, Wolter C (2015) A modelling framework to assess the effect of pressures on river abiotic habitat conditions and biota. PLoS One 10(6):e0130228. doi:10.1371/journal.pone.0130228

Kiesel J, Fohrer N, Schmalz B, White MJ (2010) Incorporating landscape depressions and tile drainages of lowland catchments into spatially distributed hydrologic modeling. Hydrol Process 24:1472-1486 
Kloecking B, Haberlandt U (2002) Impact of land use changes on water dynamics - a case study in temperate meso and macroscale river basins. Phys Chem Earth 27:619-629

Kloecking B, Stroebl B, Knoblauch S, Maier U, Pfuetzner B, Gericke A (2003) Development and allocation of land-use scenarios in agriculture for hydrological impact studies. Phys Chem Earth 28:1311-1321

Lambin EF, Rounsevell MD, Geist HJ (2000) Are agricultural land-use models able to predict changes in landuse intensity? Agricult Ecosyst Environ 82:321-331

LANU S-H (2006) Die Boeden Schleswig-Holsteins. Landesamt fuer Natur und Umwelt des Landes SchleswigHolsteins, Kiel

Laurent F, Ruelland D (2011) Assessing impacts of alternative land use and agricultural practices on nitrate pollution at the catchment scale. J Hydrol 409:440-450

Lautenbach S, Volk M, Strauch M, Whittaker G, Seppelt R (2013) Optimization-based trade-off analysis of biodiesel crop production for managing an agricultural catchment. Environ Model Software 48:98-112

Legates D, McCabe G Jr (1999) Evaluating the use of "goodness-of-fit" measures in hydrologic and hydroclimatic model validation. Water Resour Res 35(1):233-241

Liersch S (2005) Auswirkungen von Landnutzungsaenderungen und umweltgerechten Bewirtschaftungsmethoden auf den Wasser- und Stoffhaushalt des Einzugsgebietes der Ems in NordrheinWestfalen. Diplomarbeit, University of Potsdam, Institute for Geoecology

LVERMA S-H (2004) Automatisierte Liegenschaftskarte (ALK). Vermessungs- und Katasterverwaltung Schleswig-Holstein, Kiel

LVERMA S-H (1995) Digitales Hoehenmodell DHM25 (25m x 25m). Land survey office Schleswig-Holstein, Kiel

Marquardt J (2008) GIS-gestuetzte Untersuchung des Pflanzenanbaus fuer Biogasanlagen und dessen potentieller Auswirkungen auf die Beschaffenheit und den Zustand von Boden und Wasser in Schleswig-Holstein. Diplomarbeit, Leibniz Universitaet Hannover, Geographie

Moriasi DN, Arnold J, Van Liew MW, Bingner RL, Harmel RD, Veith TL (2007) Model evaluation guidelines for systematic quantification of accuracy in watershed simulations. Trans ASABE 50(3):885-900

Nash JE, Sutcliffe JV (1970) River flow forecasting through conceptual models: part I - a discussion of principles. J Hydrol 10:282-290

Neitsch S, Arnold J, Kiniry J, Williams J (2011) Soil \& Water Assessment Tool - Theoretical documentation version 2009. Texas Water Resources Institute Technical Report 406, Texas A\&M University System

Niehoff D, Fritsch U, Bronstert A (2002) Land-use impacts on storm-runoff generation: scenarios of land-use change and simulation of hydrological response in a meso-scale catchment in SW-Germany. J Hydrol 267: $80-93$

Oesterle H (2001) Reconstruction of daily global radiation for past years for use in agricultural models. Phys Chem Earth Part B, Hydrol Oceans Atmos 26(3):253-256. doi:10.1016/S14641909(00)002483

Orlowsky B, Gerstengarbe FW, Werner P (2008) A resampling scheme for regional climate simulations and its performance compared to a dynamical RCM. Theor Appl Climatol 92:209-223

Pai N, Saraswat D (2011) SWAT2009 LUC: A tool to activate the land use change module in SWAT 2009. Trans ASABE 54(5):1649-1658

Panagopoulos Y, Makropoulos C, Baltas E, Mimikou M (2011) SWAT parameterization for the identification of critical diffuse pollution source areas under data limitations. Ecol Model 222:3500-3512

Pfannerstill M, Guse B, Fohrer N (2014a) A multi-storage groundwater concept for the SWAT model to emphasize nonlinear groundwater dynamics in lowland catchments. Hydrol Process 28:5599-5612. doi: 10.1002/hyp.10062

Pfannerstill M, Guse B, Fohrer N (2014b) Smart low flow signature metrics for an improved overall performance evaluation of hydrological models. J Hydrol 510:447-458. doi:10.1016/j.jhydrol.2013.12.044

R Core Team (2013) R: A language and environment for statistical computing. R foundation for statistical computing, Vienna

Rekolainen S, Kaemaeri J, Hiltunen M, Saloranta TM (2003) A conceptual framework for identifying the need and role of models in the implementation of the water framework directive. Intl J River Basin Manag 1(4):347-352

Richter D (1995) Ergebnisse methodischer Untersuchungen zur Korrektur des systematischen Messfehlers des Hellmann-Niederschlagsmesser. Bericht des Deutschen Wetterdienstes (DWD) 194, Offenbach, DWD.

Ronfort C, Souchere V, Martin P, Sebilotte C, Castellazzi MS, Barbottin A, Meynard JM, Laignel B (2011) Methodology for land use change scenario assessment for runoff impacts: a case study in a north-western European Loess belt region (Pays de Caux, France). Catena 86:36-48

Salmoral G, Willaarts B, Troch P, Garrido A (2015) Drivers influencing streamflow changes in the Upper Turia basin, Spain. Sci Total Environ 503-504:258-268

Soetaert K, Petzoldt T (2010) Inverse modelling, sensitivity and Monte Carlo analysis in R using package FME. J Stat Softw 33:1-28

Strauch M, Lima JE, Volk M, Lorz C, Makeschin F (2013) The impact of best management practices on simulated streamflow and sediment load in a Central Brazilian catchment. J Environ Manage 127:S24-S36 
Sundermann A, Gerhardt M, Kappes H, Haase P (2013) Stressor prioritisation in riverine ecosystems: which environmental factors shape benthic invertebrate assemblage metrics? Ecol Indic 27:83-96

Ullrich A, Volk M (2009) Application of the Soil and Water Assessment Tool (SWAT) to predict the impact of alternative management practices on water quality and quantity. Agric Water Manag 96:1207-1217

Van Griensven A, Meixner T, Grunwald S, Bishop T, Di Luzio M, Srinivasan R (2006) A global sensitivity analysis tool for the parameters of multi-variable catchment models. J Hydrol 324:10-23

Veldkamp A, Lambin EF (2001) Predicting land-use change. J Agric Ecosyst Environ 85:1-6

Verburg PH, Veldkamp A (2001) The role of spatially explicit models in land-use change research: a case study for cropping patterns in China. Agric Ecosyst Environ 85:177-190

Verburg PH, Veldkamp A, Rounsevell MD (2006) Scenario-based studies of future land use in Europe. Agric Ecosyst Environ 114:1-6

Verburg P, van Berkel D, van Doorn A, van Eupen M, van den Heiligenberg H (2010) Trajectories of land use change in Europe: a model-based exploration of rural futures. Landsc Ecol 25:217-232 